\title{
Epidemic of youth nicotine addiction? What does the National Youth Tobacco Survey reveal about high school e- cigarette use in the USA? (Preprint)
}

Robert West ${ }^{1}$

1 University College London, University of London

\section{Abstract}

Background: In November 2018 the US Food and Drug Administration announced restrictions on e-cigarette manufacturers in response to a perceived epidemic of ecigarette use among high school students. The stimulus was headline figures from the 2018 National Youth T obacco Survey (NYTS). We analyse e-cigarette use and dependence in the NYTS in relation to lifetime history of use of tobacco products. Design and setting: Nationally representative survey of high school students in 2017 and 2018.

Participants: 10,186 students in 2017 and 10,991 in 2018.

Measurements: Any use of e-cigarettes in past 30 days, frequent e-cigarette use ( $\geq 20$ of past 30 days) and indicators of dependence (craving in past 30 days; use within 30 minutes of waking and days used in lifetime) were analysed in relation to lifetime tobacco product use history, ranging from never use through to lifetime smoking of $>100$ cigarettes.

Findings: Past-30-day e-cig arette use increased by $78 \%$ from $11.7 \%$ in 2017 to $20.8 \%$ in 2018 . In both years, use was strongly associated with lifetime tobacco use history: it was seen in $8.4 \%$ of never tobacco users in 2018 , in $29.0 \%$ of those who had tried a non-combustible, but never a combustible, product (OR 4.4 ( $\mathrm{Cl}$ 2.8-7.2) by comparison with never tobacco users), and in $71.0 \%$ of those who had smoked more than 100 cigarettes in their lifetime (OR 26.8, Cl 17.7-40.5) Frequent use occurred in $0.1 \%$ of never tobacco users in 2017 and $1.0 \%$ in 2018. Findings from 2014 and 2015 showed that first product tried was overwhelming ly cigarettes among those with a substantial lifetime cigarette history. Among past-30-day ecigarette users who had never tried tobacco products in 2018, 3.8\% reported craving, 3.1\% reported wanting to use within 30 minutes of waking, and $61.8 \%$ said they had used e-cigarettes on $\leq 10$ days in their life. 
Conclusions: Data from the NYTS do not support claims of a new epidemic of nicotine addiction stemming from use of e-cigarettes, nor concerns that declines in youth tobacco addiction stand to be reversed after years of progress. Among current e-cigarette users who had never tried tobacco products, responses consistently pointed to minimal dependence.

\section{Definitions}

E-cigarette

Defined by Robert West

Electronic Nicotine Delivery Device (ENDS)

Defined by Robert West

Martin J Jarvis ${ }^{1}$

m.jarvis@ucl.ac.uk

Robert JWest ${ }^{1}$

robertwest100@gmail.com

Jamie Brown ${ }^{1}$

jamie.brown@ucl.ac.uk

${ }^{1}$ Department of Behavioural Science \& Health, University College London

Declarations of interest: JB received unrestricted research funding from Pfizer, who manufacture smoking cessation medications. RW undertakes research and consultancy for and receives travel funds and hospitality from manufacturers of smoking cessation medications (Pfizer, GlaxoSmithKline and Johnson and Johnson). All authors declare no financial links with tobacco companies or e-cigarette manufacturers or their representatives.

Key words: E-cigarettes; vaping; nicotine; addiction; dependence; cigarettes; smoking.

Introduction

On November 15th 2018, the US Food and Drug Administration (FDA) released preliminary findings from the National Youth T obacco Survey (NYTS) detailing 
e-cigarette use in 2018 among US high school students (1). Compared with 2017, a 78\% increase in current (past-30-days) e-cigarette use was noted (1). At the same time, the FDA put out a press statement quoting HHS Secretary Alex Azar: "T hese new data show that America faces an epidemic of youth e-cigarette use, which threatens to engulf a new generation in nicotine addiction."(2) A statement from (then current, now former) FDA Commissioner Scott Gottlieb, issued on the same day, said: "The data show that kids using e-cigarettes are going to be more likely to try combustible cigarettes later. This is a large pool of future risk. ... The data from this nationally representative survey.... show astonishing increases in kids' use of e-cigarettes and other ENDS, reversing years of favorable trends in our nation's fight to prevent youth addiction to tobacco products. These data shock my conscience"(3). Gottlieb announced a series of regulatory initiatives to address the perceived problem of youth e-cigarette use. The FDA moves were based on their analysis of preliminary data from the 2018 NYTS, received in September 2018. Their publicly revealed analysis did not consider how e-cigarette use in high school students was related to patterns of use of combustible tobacco products, especially cig arettes.

In February 2019, a further report was published (4), giving more detailed tables, and giving data on frequent use (defined as on 20 or more days in the past 30 days). "During 2017-2018, frequent e-cigarette use increased significantly by 38.5\% among current ecigarette users (from $20.0 \%$ to $27.7 \%$ ); no significant change in frequent use was observed for other tobacco products". Commissioner Gottlieb issued a further statement on the same day, in which he continued to raise serious concerns: "T hese data are a sobering reminder of the initial results we shared last fall indicating a rampant rise of youth e-cigarette use, which has prompted the FDA to take a series of escalating regulatory actions ......... I will not allow a generation of children to become addicted to nicotine through e-cigarettes." "This is an exploding epidemic. We'll continue to put the full scope of our regulatory tools against this mounting public health crisis.." (5)

In the UK use of e-cigarettes by adolescents has not attracted such concern. Commentators have noted that e-cigarette use is strongly associated with cigarette smoking in children and rare amongst never smokers (6-8). The NYTS public use data file for the 2018 survey became available in March 2019. In this paper we analyse ecigarette use and indicators of tobacco dependence in the NYTS in relation to lifetime history of other tobacco products. We employ data from the 2014 and 2015 NYTS to examine which product was tried first in tobacco users' careers. We also report on time trends in prevalence of e-cigarette and combustible tobacco use in the USA. 
Methods

Data

The National Youth Tobacco Survey (NYTS) is designed to produce a nationally representative cross-sectional sample of students from US middle and high schools. It was developed to inform national and state tobacco prevention and control programs. Full details of the NYTS methodology are available elsewhere (9) Briefly, a three-stage cluster sampling procedure is used to generate a nationally representative sample of students in grades 6-12. Of 310 schools selected for the 2018 NYTS 238 (76.8\%) participated, with an achieved sample of 20,189 (88.8\%) among 22,729 students; the overall response rate, calculated as the product of the school-level and student-level participation rates, was $63.4 \%$ (9). The NYTS employs an anonymous, self-administered questionnaire to enquire about ever and current use of cigarettes, cigars (defined as cigars, cigarillos, or little cigars), other combustible tobacco (pipes, bidis, hookahs); noncombustible tobacco (chewing tobacco, snuff, or dip, snus, and dissolvable tobacco); and e-cigarettes. Both current use (defined as any use of each product in the past 30 days) and ever-use (ever trying) are ascertained.

We derived a measure of lifetime tobacco product use history as follows: Respondents were asked "About how many cig arettes have you smoked in your entire life?" with 7 response options going from "I have never smoked cigarettes, not even one or two puffs" through "100 or more cigarettes (5 or more packs)". We added further categories for those who reported ever-use of e-cigarettes but no other tobacco product; a noncombustible tobacco product, but never any combustible; and use of a combustible product (cigars, pipes, bidi, hookah) but never cigarettes. Thus there were 10 response categories in all for lifetime tobacco use history, ranging from never use of any tobacco product through to smoking of more than 100 cigarettes.

Statistical analysis

We used the complex survey analysis module in SPSS 24 to adjust for the sampling design of the survey and to generate estimates ( $\pm 95 \%$ confidence intervals) applicable to the US population. We examined the univariate association between current use of ecigarettes and our measure of lifetime tobacco product use history. We employed a logistic regression analysis to derive estimates of the odds ratios ( $\pm 95 \% \mathrm{Cls})$ for current 
e-cigarette use. We conducted similar analyses to examine use of e-cig arettes for 1-19 days and 20 or more days within the past 30 days. We examined responses to other questions (e.g. "During the past 30 days, have you had a strong craving or felt like you really needed to use a tobacco product of any kind?"; and "How soon after you wake up do you want to use a tobacco product?" to provide an indication of dependence. We focused on high school students (sample size 10,186 in 2017 and 10,991 in 2018). Our report focuses primarily on data from the NYTS surveys conducted in 2017 and 2018, but we carried out similar analyses for the years 2014-2016 (results in supplementary tables available online). In order to get some pointers towards the issue of which tobacco products were used first and which subsequently in high school students' using careers, we examined responses to the question "'Which of the following tobacco products did you try first?", asked in 2014; and in 2015 "Which of the following statements best applies to your cigarette or electronic cigarette use?" (Response options: I have never tried cigarettes or electronic cigarettes; I have only tried cigarettes; I have only tried electronic cigarettes; I tried cigarettes before I ever tried electronic cigarettes; I tried electronic cigarettes before I ever tried cigarettes). Neither of these questions were asked in the 2017 or 2018 surveys.

\section{Results}

The overall prevalence of past-30-days e-cigarette use among high school students in 2018 was $20.8 \%$, an increase of 78\% from the observed figure of $11.7 \%$ in 2017 (T able 1). Prevalence was strongly associated with lifetime tobacco use history in both years: among never tobacco users, $2.9 \%$ in 2017 and $8.4 \%$ in 2018 were past-30-days ecigarette users, whilst among those who had smoked more than 100 cigarettes in their lifetime, the corresponding figures were $57.2 \%$ in 2017 and $71.0 \%$ in 2018. By comparison with never tobacco users, the odds of current e-cigarette use rose steeply and in a graded fashion with extent of tobacco experience. In 2018, the odds ratio among those who had minimal tobacco experience (had tried a non-combustible but never a combustible product) were already significantly raised, (OR 4.4), while in those who had smoked just one cigarette the odds ratio was 7.1, rising to 26.8 in those who had smoked more than 100 cigarettes in their lifetime. Similar associations with lifetime tobacco use history were observed in 2017. Past-30-days cigarette smoking was strongly associated with cigarette use history in both years, and reached 88.4\% in 2017 and $84.5 \%$ in 2018 in students who had smoked 100+ cigarettes in their lifetime. 
In both 2017 and 2018, about one quarter of past-30-days e-cigarette users reported having used them on 20 or more days (19.9\%, 210/1,051 and 28.4\%, 627/2207). This heavier use was strongly associated with lifetime tobacco use history: it was seen in only $0.1 \%$ of never tobacco users in 2017 and $1.0 \%$ in 2018. The observed frequency of $20+$ days use increased with the extent of lifetime tobacco use, and reached $26.8 \%$ in 2017 and $37.2 \%$ in 2018 among students who had smoked more than 100 cigarettes. Indicators of dependence in e-cigarette users

Table 2 shows responses to questions indicating aspects of dependence and tobacco use behaviour by lifetime tobacco use history. Among students who were past-30-day ecigarette users but had never tried any non-combustible or combustible tobacco product, responses consistently pointed to minimal or absent dependence. In 2018, in response to the question "Are you seriously thinking about quitting the use of all tobacco products?" $49.4 \%$ of e-cigarette users with no history of ever trying other tobacco products selected the response option "I do not use tobacco products", and similarly, asked "During the past 30 days, on how many days did you use any tobacco product(s)?", 55.4\% chose the 0 days option. Only 3.8\% reported any experience of craving for tobacco products, and 3.1\% reported wanting to use within 30 minutes. Nearly $90 \%$ of responses to the question "How soon after you wake up do you want to use a tobacco product?" were comprised by "I do not want to use tobacco" (60.4\%) and "I rarely want to use tobacco" (28.1\%). 12.7\% said they had used e-cigarettes on only one day in their life, and a further $49.1 \%$ had used them on between 1 and 10 days. This pattern of responding contrasted markedly with that seen in e-cigarette users with a lifetime history of smoking more than 100 cigarettes: $74.5 \%$ of these reported experiencing craving; $51.4 \%$ wanted to use within 30 minutes of waking, and only $8.8 \%$ said "'I do not want to use tobacco" and $6.4 \%$ that they rarely wanted to use. The pattern of responses to these dependence indicators by lifetime tobacco use history was similar in 2017 (Table 2, top).

Which product used first by tobacco use history

Table 3 shows, by lifetime tobacco use history, which product respondents reported using first in their tobacco career. The more cigarettes students reported having smoked in their lifetime, the higher the chances were that cigarettes were the first product used: in 2014, just over three quarters (75.6\%) of current e-cigarette users who had smoked more than 100 cigarettes named cigarettes as the first tobacco product they had used, while just 2.2\% had used e-cigarettes first. Among those who had smoked a few puffs but never a whole cigarette in their lifetime, $49.3 \%$ reported the 
cig arette as first product used and $18.8 \%$ had first used e-cigarettes. In 2015, $87.7 \%$ of current e-cigarette smokers who had smoked more than 100 cigarettes said cigarettes were the first product they had tried, while $7.6 \%$ identified e-cigarettes as the first product tried. Among those who had had just a few puffs of a cigarette in their lifetime, $53.1 \%$ had tried cigarettes first, and $25.4 \%$ had tried e-cigarettes first.

Trends in use of cigarettes, combustibles and e-cigarettes in NYTS 1999-2018

There has been a continuing decline in current cigarette smoking in high school students, from $28.5 \%$ in 1999 to $8.1 \%$ in 2018 (see Figure). The proportion who have ever tried a combustible product has likewise declined from $66.9 \%$ in 1999 to $33.4 \%$ in 2018 . The advent of e-cigarettes, first monitored in the 2011 NYTS, appears to have had little if any impact on this declining trend. Prevalence of past-30-day e-cig arette use rose from $1.4 \%$ in 2011 to $20.8 \%$ in 2018 . The increase in the proportion who have ever tried an ecigarette has been even more marked, going from 4.5\% in 2011 to $36.6 \%$ in 2018. This has occurred without any discernible impact on the slope of declining cigarette and combustible use.

\section{Discussion}

Our analysis of data from the NYTS confirms the headline sharp uptick in past-30-day use of e-cigarettes which prompted the FDA's urgent regulatory initiatives in November 2018. In bringing forward proposals for regulatory action, the FDA did not place ecigarette use in the context of use of other tobacco products. Our analysis of NYTS data from 2018 and earlier years shows a strong association between lifetime history of use of tobacco products and use of e-cigarettes: in 2018, high school students who had smoked more than 100 cigarettes in their lifetime were some 27 times more likely to have used e-cigarettes in the past 30 days than students who had never tried any tobacco product. Use of e-cigarettes on 20 or more days in the past month was seen in only $1.0 \%$ of those who had never tried any tobacco product in 2018.

It is notoriously problematic to draw inferences about direction of causality from crosssectional data. In principle, the strong and graded association observed between likelihood of using e-cigarettes in the past 30 days and lifetime history of use of tobacco products could point to an effect of using e-cigarettes on subsequent uptake and use of cigarettes and other combustible products. This appears to be the view adopted by the FDA. While it may well be the case that in some individual instances initial trying of an e- 
cigarette led on to trying and using cigarettes, the data strongly suggest that this is not the dominant pattern observed at the level of the whole population. Among high school students we found that, for the great majority of those with any substantial cigarette smoking history, cigarettes were the first tobacco product tried, prior to any use of ecigarettes. Clearly, for these students their use of cigarettes and the development of characteristic nicotine dependence must be attributed to cigarettes as the uptake product, rather than to e-cigarettes. Similarly, the observed rapid decline in trying combustible products and in the prevalence of cigarette smoking since 1999 has not yet given any sign of being reversed through the upsurge of e-cigarette use since 2011 (10). At the population level, therefore, the NYTS fails to give evidence of e-cigarettes acting as a gateway to smoking in adolescents. In these circumstances, there is plausibility to the suggestion that e-cigarettes are likely to reduce the disease burden in the US by helping adult smokers to quit (11).

We found little evidence of substantial nicotine addiction attributable to the use of ecigarettes. Among all students who were past-30-day-cigarette users but had never tried tobacco products, responses consistently pointed to minimal dependence with only $3.8 \%$ reporting any craving for tobacco products, and $3.1 \%$ reporting wanting to use within 30 minutes of waking. Over $60 \%$ reporting using a cigarette on 10 or fewer days in their lifetime. Only 3.4\% were classified as frequent users of e-cigarettes on 20 or more days in the past month. This contrasted markedly with students who had smoked more than 100 cigarettes (so meeting the US definition for regular cigarette smoking), where 74.5\% reported craving, 51.4\% wanted to use within 30 minutes of waking, $52.4 \%$ used e-cigarettes on 20 or more days in the past month, and $64.0 \%$ had used e-cigs on more than 100 days in their lifetime. This group had mostly started their tobacco careers with cigarettes, and their pattern of dependence typifies that attributable to cigarette use.

In 2014, the FDA deemed e-cigarettes to be a tobacco product and so brought them within their regulatory competence. It appears that high school students in the US disagree with the FDA's classificatory scheme, as close to half of past-30-day e-cigarette users who had never tried any other tobacco products denied using a tobacco product in the past month. At the very least, this suggests their self-concept is not that of being a tobacco product user. This perception of e-cigarettes as something different and separate from tobacco could serve to reduce their chances of progression to using conventional tobacco products. In summary, data from the NYTS survey do not provide support for claims of a new epidemic of nicotine addiction stemming from use of e-cigarettes, nor for concerns that 
declines in youth tobacco addiction stand to be reversed after years of progress.

Symptoms of dependence were rare among students who use e-cigarettes without having used any other tobacco products.

This paper is not intended as a challenge to the current direction of FDA policy on the regulation of e-cigarettes. That would be presumptuous on our part. Rather, we have sought to examine the evidence brought forward to support new regulatory initiatives. We find a gaping chasm between the vision of an epidemic of e-cigarette use threatening to engulf a new generation in nicotine addiction and the reality of the evidence contained in the NYTS. As patterns of youth nicotine and tobacco use continue to evolve, careful surveillance of survey findings will remain of critical importance.

Funding

Cancer Research UK funded JB's salary (C1417/A22962). The funders had no final role in the study design; in the collection, analysis and interpretation of data; in the writing of the report; or in the decision to submit the paper for publication. All researchers listed as authors are independent from the funders and all final decisions about the research were taken by the investigators and were unrestricted.

\begin{tabular}{|c|c|c|c|c|c|c|c|c|c|c|c|}
\hline & \multicolumn{11}{|c|}{ Lifetime tobacco use history } \\
\hline & \begin{tabular}{|l|} 
Never \\
used any \\
tobacco \\
product \\
\end{tabular} & \begin{tabular}{|l|} 
Used \\
tobacco, but \\
not \\
combustible
\end{tabular} & \begin{tabular}{|l|}
$\begin{array}{l}\text { Tried } \\
\text { combustible, } \\
\text { but not } \\
\text { cigarette }\end{array}$ \\
\end{tabular} & \begin{tabular}{|l|}
1 or more \\
puffs, but \\
never whole \\
cigarette
\end{tabular} & 1 cigarette & \begin{tabular}{|l|}
2 to 5 \\
cigarettes
\end{tabular} & \begin{tabular}{|l|}
6 to 15 \\
cigarettes
\end{tabular} & \begin{tabular}{|l|}
16 to 25 \\
cigarettes
\end{tabular} & \begin{tabular}{|l|}
26 to 99 \\
cigarettes
\end{tabular} & \begin{tabular}{|l|}
$100+$ \\
cigarettes
\end{tabular} & Total \\
\hline $\begin{array}{l}\text { Used 1-19 } \\
\text { day5\% }\end{array}$ & \begin{tabular}{|l|}
2.8 \\
$(2.0-3.8)$ \\
\end{tabular} & \begin{tabular}{|l|}
15.7 \\
$(8.7-26.7)$
\end{tabular} & \begin{tabular}{|l|}
16.1 \\
$(13.1-19.3)$
\end{tabular} & \begin{tabular}{|l|}
15.2 \\
$(11.8-19.3)$ \\
\end{tabular} & $\begin{array}{l}21.1 \\
(14.8-29.1)\end{array}$ & \begin{tabular}{|l|}
29.4 \\
$(24.0-35.4)$
\end{tabular} & \begin{tabular}{|l|}
27.8 \\
$(20.6-36.5)$
\end{tabular} & \begin{tabular}{|l|}
33.3 \\
$(24.0-44.2)$ \\
\end{tabular} & \begin{tabular}{|l|}
31.0 \\
$(23.0-40.2)$ \\
\end{tabular} & \begin{tabular}{|l|}
31.5 \\
$(25.6-38.1)$ \\
\end{tabular} & $\begin{array}{l}9.3 \\
(7.8-10.9)\end{array}$ \\
\hline $\mathrm{N}$ & 165 & 23 & 144 & 123 & 29 & 108 & 59 & 33 & 60 & 97 & 841 \\
\hline $\begin{array}{l}\text { Used 20+ days } \\
\%\end{array}$ & \begin{tabular}{|l|}
0.2 \\
$(0.1-0.4)$ \\
\end{tabular} & \begin{tabular}{|l|}
1.7 \\
$(0.4-7.0)$
\end{tabular} & \begin{tabular}{|l|}
2.3 \\
$(1.3-3.9)$ \\
\end{tabular} & \begin{tabular}{|l|}
2.7 \\
$(1.5-4.8)$ \\
\end{tabular} & $\begin{array}{l}2.8 \\
(1.0-7.3)\end{array}$ & \begin{tabular}{|l|}
3.4 \\
$(1.9-6.0)$ \\
\end{tabular} & \begin{tabular}{|l|}
11.3 \\
$(7.1-17.5)$ \\
\end{tabular} & \begin{tabular}{|l|}
8.0 \\
$(3.9-15.8)$ \\
\end{tabular} & \begin{tabular}{|l|}
13.4 \\
$(7.6-22.7)$
\end{tabular} & \begin{tabular}{|l|}
26.8 \\
$(18.5-37.2)$ \\
\end{tabular} & $\begin{array}{l}2.3 \\
(1.6-3.3)\end{array}$ \\
\hline $\mathrm{N}$ & 8 & 2 & 24 & 20 & 4 & 14 & 26 & 15 & 20 & 77 & 210 \\
\hline $\begin{array}{l}\text { Any past } 30 \\
\text { days use }\end{array}$ & \begin{tabular}{|l|}
2.9 \\
$(2.1-4.0)$ \\
\end{tabular} & \begin{tabular}{|l|}
17.3 \\
$(10.3-27.5)$
\end{tabular} & \begin{tabular}{|l|}
18.6 \\
$(15.3-22.5)$
\end{tabular} & \begin{tabular}{|l|}
18.2 \\
$(13.9-23.3)$ \\
\end{tabular} & $\begin{array}{l}23.2 \\
(16.4-31.8)\end{array}$ & \begin{tabular}{|l|}
33.1 \\
$(27.2-39.5)$
\end{tabular} & \begin{tabular}{|l|}
38.5 \\
$(28.1-50.1)$
\end{tabular} & \begin{tabular}{|l|l|}
41.3 \\
$(30.8-52.7)$ \\
\end{tabular} & \begin{tabular}{|l|}
44.4 \\
$(37.1-52.0)$ \\
\end{tabular} & \begin{tabular}{|l|}
57.2 \\
$(47.1-66.7)$ \\
\end{tabular} & $\begin{array}{l}11.7 \\
(9.8-13.8)\end{array}$ \\
\hline & 173 & 25 & 168 & 143 & 33 & 122 & 85 & 48 & 80 & 174 & 1066 \\
\hline Base & 6341 & 153 & 1110 & 888 & 173 & 393 & 216 & 124 & 193 & 326 & 10015 \\
\hline OR & 1.00 & \begin{tabular}{|l|}
6.94 \\
$(3.7-12.9)$ \\
\end{tabular} & \begin{tabular}{|l|}
7.6 \\
$(5.7-10.2)$ \\
\end{tabular} & \begin{tabular}{|l|}
7.4 \\
$(5.4-10.1)$ \\
\end{tabular} & $\begin{array}{l}10.1 \\
(6.0-16.8) \\
\end{array}$ & \begin{tabular}{|l|}
16.4 \\
$(11.7-23.0)$ \\
\end{tabular} & \begin{tabular}{|l|}
20.8 \\
$(12.2-35.5)$
\end{tabular} & \begin{tabular}{|l|}
33.4 \\
$(15.3-35.6)$ \\
\end{tabular} & \begin{tabular}{|l|}
26.5 \\
$(17.7-39.8)$ \\
\end{tabular} & \begin{tabular}{|l|}
44.4 \\
$(27.9-70.7)$ \\
\end{tabular} & \\
\hline $\begin{array}{l}\text { Smoked cigs in } \\
\text { past } 30 \text { days } \%\end{array}$ & - & - & \begin{tabular}{|l|}
0.1 \\
$(0-0.7)$ \\
\end{tabular} & \begin{tabular}{|l|}
4.2 \\
$(3.1-5.7) \mid$ \\
\end{tabular} & $\begin{array}{l}10.7 \\
(6.0-18.4) \\
\end{array}$ & \begin{tabular}{|l|}
28.4 \\
$(22.0-34.9)$ \\
\end{tabular} & \begin{tabular}{|l|}
46.3 \\
$(35.6-57.4)$ \\
\end{tabular} & $\begin{array}{l}61.6 \\
(50.3-71.8) \\
\end{array}$ & $\begin{array}{l}69.8 \\
(59.7-78.2) \\
\end{array}$ & \begin{tabular}{|l|}
88.4 \\
$(81.2-93.1)$ \\
\end{tabular} & $\begin{array}{l}7.6 \\
(6.5-8.8)\end{array}$ \\
\hline \multirow{2}{*}{\multicolumn{12}{|c|}{ NYTS 2017}} \\
\hline & & & & & & & & & & & \\
\hline & $\begin{array}{l}\text { Never used } \\
\text { any } \\
\text { tobacco } \\
\text { product } \\
\end{array}$ & \begin{tabular}{|l|} 
Used \\
tobacco, but \\
not \\
combustible
\end{tabular} & \begin{tabular}{|l|} 
Tried \\
combustible, \\
but not \\
cigarette \\
\end{tabular} & \begin{tabular}{|l|}
1 or more \\
puffs, but \\
never whole \\
cigarette \\
\end{tabular} & 1 cigarette & $\begin{array}{l}2 \text { to } 5 \\
\text { cigarettes }\end{array}$ & $\begin{array}{l}6 \text { to } 15 \\
\text { cigarettes }\end{array}$ & $\begin{array}{l}16 \text { to } 25 \\
\text { cigarettes }\end{array}$ & $\begin{array}{l}26 \text { to } 99 \\
\text { cigarettes }\end{array}$ & $\begin{array}{l}100+ \\
\text { cigarettes }\end{array}$ & Total \\
\hline $\begin{array}{l}\text { Used 1-19 } \\
\text { days\% }\end{array}$ & \begin{tabular}{|l|}
7.4 \\
$(6.2-8.9)$ \\
\end{tabular} & \begin{tabular}{|l|}
23.8 \\
$(16.3-33.3)$ \\
\end{tabular} & \begin{tabular}{|l|}
23.4 \\
$(19.2-28.2)$ \\
\end{tabular} & \begin{tabular}{|l|}
24.1 \\
$(20.2-28.4)$ \\
\end{tabular} & \begin{tabular}{|l|}
31.4 \\
$(24.1-39.8)$
\end{tabular} & $\begin{array}{l}37.9 \\
(31.8-44.4) \\
\end{array}$ & $\begin{array}{l}35.5 \\
(28.7-42.9) \\
\end{array}$ & $\begin{array}{l}33.6 \\
(25.2-43.1) \\
\end{array}$ & $\begin{array}{l}31.7 \\
(23.6-40.7) \\
\end{array}$ & $\begin{array}{l}33.8 \\
(28.4-39.6) \\
\end{array}$ & $\begin{array}{l}15.0 \\
(13.7-16.5)\end{array}$ \\
\hline $\mathrm{N}$ & 490 & 36 & 253 & 209 & 66 & 162 & 91 & 58 & 75 & 140 & 1580 \\
\hline $\begin{array}{l}\text { Used 20+ days } \\
\%\end{array}$ & \begin{tabular}{|l|}
1.0 \\
$(0.7-1.4)$
\end{tabular} & \begin{tabular}{|l|}
5.2 \\
$(2.4-11.1)$ \\
\end{tabular} & \begin{tabular}{|l|}
4.9 \\
$(3.2-7.6)$
\end{tabular} & \begin{tabular}{|l|}
7.4 \\
$(5.3-10.4)$ \\
\end{tabular} & \begin{tabular}{|l|}
8.0 \\
$(4.9-12.8)$
\end{tabular} & $\begin{array}{l}15.0 \\
(10.6-20.8)\end{array}$ & $\begin{array}{l}19.7 \\
(12.6-29.3)\end{array}$ & $\begin{array}{l}33.2 \\
(24.7-43.1)\end{array}$ & $\begin{array}{l}36.3 \\
(27.7-45.8)\end{array}$ & $\begin{array}{l}37.2 \\
(29.8-45.4)\end{array}$ & $\begin{array}{l}5.7 \\
(4.8-6.8)\end{array}$ \\
\hline $\mathrm{N}$ & 60 & 10 & 66 & 64 & 19 & 71 & 39 & 55 & 80 & 163 & 627 \\
\hline $\begin{array}{l}\text { Any past } 30 \\
\text { days use }\end{array}$ & \begin{tabular}{|l|}
8.4 \\
$(7.0-10.1)$ \\
\end{tabular} & \begin{tabular}{|l|}
29.0 \\
$(20.6-39.1)$
\end{tabular} & \begin{tabular}{|l|}
28.3 \\
$(23.7-33.4)$
\end{tabular} & \begin{tabular}{|l|}
31.5 \\
$(26.4-37.1)$ \\
\end{tabular} & \begin{tabular}{|l|}
39.4 \\
$(31.3-48.1)$
\end{tabular} & $\begin{array}{l}52.9 \\
(45.9-59.9)\end{array}$ & $\begin{array}{l}55.1 \\
(46.5-63.4)\end{array}$ & $\begin{array}{l}66.8 \\
(55.5-76.4)\end{array}$ & $\begin{array}{l}68.0 \\
(59.2-75.6)\end{array}$ & $\begin{array}{l}71.0 \\
(62.9-78.0)\end{array}$ & $\begin{array}{l}20.8 \\
(18.8-22.8)\end{array}$ \\
\hline $\mathrm{N}$ & 550 & 46 & 319 & 273 & 85 & 233 & 130 & 113 & 155 & 303 & 2207 \\
\hline Base & 6664 & 225 & 1194 & 902 & 209 & 464 & 241 & 175 & 240 & 433 & 10708 \\
\hline OR & & \begin{tabular}{|l|}
4.4 \\
$(2.8-7.2)$
\end{tabular} & \begin{tabular}{|l|}
4.3 \\
$(3.4-5.5)$
\end{tabular} & \begin{tabular}{|l|}
5.0 \\
$(4.0-6.4)$ \\
\end{tabular} & \begin{tabular}{|l|}
7.1 \\
$(5.0-10.0)$
\end{tabular} & $\begin{array}{l}12.3 \\
(9.1-16.6)\end{array}$ & $\begin{array}{l}13.4 \\
(9.6-18.9)\end{array}$ & $\begin{array}{l}22.0 \\
(13.3-36.3)\end{array}$ & $\begin{array}{l}23.2 \\
(15.5-34.6)\end{array}$ & $\begin{array}{l}26.8 \\
(17.7-40.5)\end{array}$ & \\
\hline $\begin{array}{l}\text { Smoked cigs in } \\
\text { past } 30 \text { days } \%\end{array}$ & & & $\begin{array}{l}0.1 \\
(0.0-0.9)\end{array}$ & \begin{tabular}{|l|}
5.4 \\
$(3.8-7.6)$
\end{tabular} & \begin{tabular}{|l|}
13.4 \\
$(8.6-20.2)$
\end{tabular} & $\begin{array}{l}29.2 \\
(24.1-34.7)\end{array}$ & $\begin{array}{l}48.5 \\
(39.8-57.3)\end{array}$ & $\begin{array}{l}56.0 \\
(44.8-66.5)\end{array}$ & $\begin{array}{l}63.6 \\
(55.7-70.8)\end{array}$ & $\begin{array}{l}84.5 \\
(80.6-87.8)\end{array}$ & $\begin{array}{l}8.1 \\
(7.1-9.3)\end{array}$ \\
\hline
\end{tabular}


Table 2 Indicators of dependence in current e-cigarette users by lifetime tobacco use history: high school students NYTS 2017(top) and 2018 (bottom)

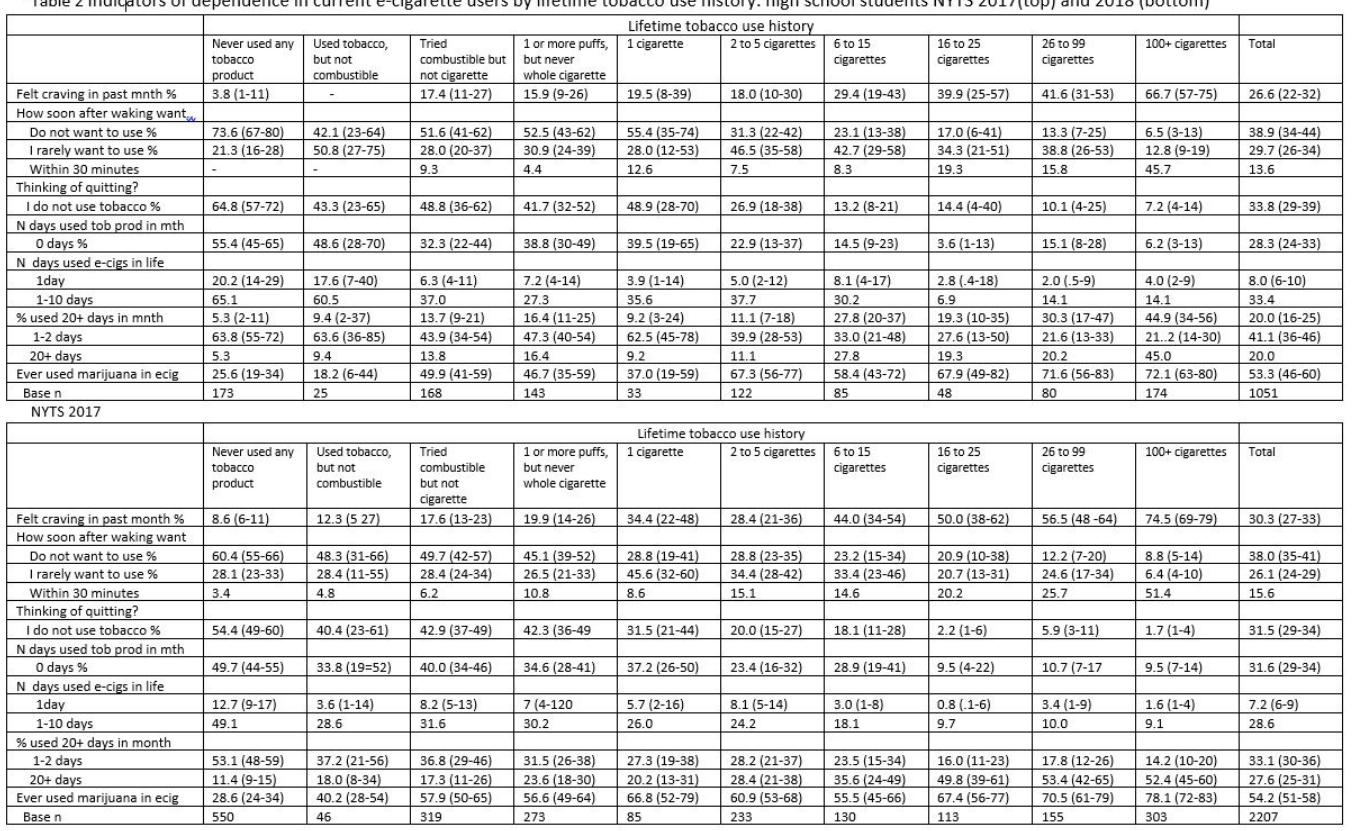

Table 3: Temporal order of first use of e-cigarettes and cigarettes by lifetime tobacco use history: among current (past 30 days) e-cigarette users.

\begin{tabular}{|c|c|c|c|c|c|c|c|c|c|c|c|}
\hline & \multicolumn{10}{|c|}{ Lifetime tobacco use history } & \multirow[b]{2}{*}{ Total } \\
\hline & $\begin{array}{l}\text { Never used } \\
\text { any tobacco } \\
\text { product }\end{array}$ & \begin{tabular}{|l|} 
Used \\
tobacco, but \\
not \\
combustible
\end{tabular} & \begin{tabular}{|l|} 
Tried \\
combustible, \\
but not \\
cigarette \\
\end{tabular} & $\begin{array}{l}1 \text { or more } \\
\text { puffs, but } \\
\text { never whole } \\
\text { cigarette }\end{array}$ & 1 cigarette & $\begin{array}{l}2 \text { to } 5 \\
\text { cigarettes }\end{array}$ & \begin{tabular}{|l|}
6 to 15 \\
cigarettes
\end{tabular} & \begin{tabular}{|l|}
$\begin{array}{l}16 \text { to } 25 \\
\text { cigarettes }\end{array}$ \\
\end{tabular} & $\begin{array}{l}\begin{array}{l}26 \text { to } 99 \\
\text { cigarettes }\end{array} \\
\end{array}$ & $\begin{array}{l}100+ \\
\text { cigarettes }\end{array}$ & \\
\hline Cigarettes & $0.6(1-9)$ & \begin{tabular}{|l}
$2.9(3-20.7)$ \\
\end{tabular} & $1.8(5-6)$ & $49.3(42-57)$ & $65.7(50-78)$ & $55.4(47-64)$ & $58.2(46-70)$ & $62.3(49-74)$ & $64.9(51-77)$ & $76.5(70-82)$ & $47.5(43-52)$ \\
\hline $\mathrm{N}$ & 1 & 1 & 5 & 92 & 38 & 104 & 77 & 52 & 77 & 237 & 684 \\
\hline Cigars, cigarillos \% & & & $23.3(15-34)$ & $14.9(9-24)$ & $6.7(3-17)$ & $17.4(12-25)$ & $12.3(7-20)$ & $9.9(5-18)$ & $15.9(9-28)$ & $8.8(6-12)$ & $12.7(10-15)$ \\
\hline $\mathrm{N}$ & 0 & 0 & 45 & 26 & 4 & 29 & 18 & 9 & 19 & 32 & 182 \\
\hline Chew, snuff, dip \% & & $48.3(25-73)$ & $12.9(9-19)$ & $8.7(5-16)$ & $5.6(2-14)$ & $10.5(5.5-19.4)$ & $7.6(4-14)$ & $16.7(9-29)$ & $15.0(9-24)$ & $8.6(5-14)$ & $9.7(7-13)$ \\
\hline $\mathrm{N}$ & 0 & 7 & 25 & 14 & 4 & 13 & 10 & 12 & 19 & 28 & 132 \\
\hline E-cigarettes & \begin{tabular}{|l}
$87.1(81-91)$ \\
\end{tabular} & \begin{tabular}{|l}
$48.9(25-74)$ \\
\end{tabular} & \begin{tabular}{|l}
$49.8(40-62)$ \\
\end{tabular} & $18.8(14-26)$ & $13.4(7-26)$ & $8.7(5-15)$ & $15.3(7-31)$ & $8.0(3-19)$ & $2.1(0.7-6.0)$ & $2.2(1-4)$ & $22.9(19-27)$ \\
\hline $\mathrm{N}$ & 123 & 5 & 98 & 45 & 我 & 17 & 17 & 5 & 4 & 8 & 330 \\
\hline Base & 146 & 13 & 204 & 194 & 59 & 177 & 128 & 83 & 122 & 317 & 1443 \\
\hline
\end{tabular}

NYTS 2014

\begin{tabular}{|c|c|c|c|c|c|c|c|c|c|c|c|}
\hline & \multicolumn{10}{|c|}{ Lifetime tobacco use history } & \multirow[b]{2}{*}{ Total } \\
\hline & $\begin{array}{l}\text { Never used } \\
\text { any tobacco } \\
\text { product }\end{array}$ & \begin{tabular}{|l|} 
Used \\
tobacco, but \\
not \\
combustible \\
\end{tabular} & \begin{tabular}{|l|} 
Tried \\
combustible, \\
but not \\
cigarette \\
\end{tabular} & \begin{tabular}{|l|}
$\begin{array}{l}1 \text { or more } \\
\text { puffs, but } \\
\text { never whole } \\
\text { cigarette }\end{array}$ \\
\end{tabular} & 1 cigarette & \begin{tabular}{|l|}
2 to 5 \\
cigarettes
\end{tabular} & \begin{tabular}{|l|}
$\begin{array}{l}6 \text { to } 15 \\
\text { cigarettes }\end{array}$ \\
\end{tabular} & \begin{tabular}{|l|}
$\begin{array}{l}16 \text { to } 25 \\
\text { cigarettes }\end{array}$ \\
\end{tabular} & \begin{tabular}{|l|}
$\begin{array}{l}26 \\
\text { cigarettes }\end{array}$ \\
\end{tabular} & \begin{tabular}{|l|}
$100+$ \\
cigarettes
\end{tabular} & \\
\hline $\begin{array}{l}\text { Only tried } \\
\text { cigarettes }\end{array}$ & $0.7(.1-5)$ & & $1.2(.4-4)$ & $2.5(.5-10)$ & & $1.4(.4-5)$ & $1.4(\cdot 3-6)$ & $4.1(1.3-12)$ & $1.1(.3-4)$ & $2.2(1-5)$ & $1.6(1-3)$ \\
\hline$n$ & 1 & 0 & 4 & 3 & & 3 & 2 & 3 & 2 & 6 & 24 \\
\hline Only tried e-cigs & 87.1 (79-92) & \begin{tabular}{|l}
$92.2(76-98)$ \\
\end{tabular} & $84.7(79-89)$ & $15.5(11-22)$ & $5.4(.8-29)$ & $5.6(3-12)$ & $2.5(.5-11)$ & $5.0(1-20)$ & & $0.7(.2-2.0)$ & $30.2(27-34)$ \\
\hline $\mathrm{n}$ & 133 & 20 & 233 & \begin{tabular}{|l|l|}
29 \\
\end{tabular} & 1 & 9 & 3 & 2 & & 3 & 433 \\
\hline Tried cigs first & & & $1.2(.4-3)$ & \begin{tabular}{|l|}
$53.1(45-61)$ \\
\end{tabular} & $50.4(37-64)$ & \begin{tabular}{|l|l|}
$67.7(59-76)$ \\
\end{tabular} & $73.5(62-82)$ & \begin{tabular}{|l|l|}
$76.8(64-86)$ \\
\end{tabular} & $82.9(69-92)$ & \begin{tabular}{|l|l|}
$87.7(82-92)$ \\
\end{tabular} & $50.0(46-55)$ \\
\hline$n$ & & & 3 & \begin{tabular}{|l|l|}
106 \\
\end{tabular} & \begin{tabular}{|l|l|}
27 \\
\end{tabular} & 123 & 80 & 54 & 85 & 231 & 709 \\
\hline Tried e-cigs first & $5.7(3-12)$ & $3.3(.4-23)$ & $9.7(6-15)$ & 25.4 (19-34) & $40.2(26-56)$ & $21.5(16-29)$ & $21.6(13-33)$ & $13.3(7-24)$ & $15.3(7-30)$ & $7.6(4-13)$ & $15.2(13-17)$ \\
\hline $\mathrm{N}$ & 9 & 1 & 26 & 56 & 17 & 40 & 23 & 10 & 12 & 17 & 211 \\
\hline Base & 151 & 23 & 273 & 202 & 47 & 183 & 110 & 70 & 100 & 263 & 1422 \\
\hline
\end{tabular}

NYTS 2015 


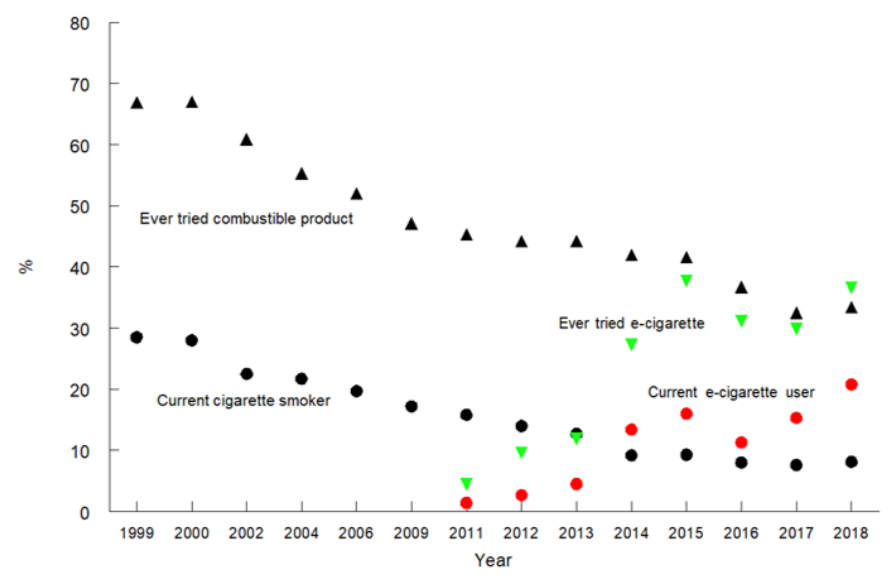

Figure 1

Time trends in use of e-cigarettes (ever-tried \& current) and combustible (ever-tried combustible product and current cigarette) NYTS 1999-2018. E-cigarette use ascertained from 2011 onwards

References

1. Cullen KA AB, Gentzke AS, Apelberg BJ, Jamal A, King BA. . Notes from the Field: Use of Electronic Cigarettes and Any Tobacco Product Among Middle and High School Students — United States, 2011-2018. MMWR Morb Mortal Wkly Rep. 2018;67:1276-7. 2. Results from 2018 National Youth Tobacco Survey show dramatic increase in ecigarette use among youth over past year. [press release]. November 15th 2018: .

3. Statement from FDA Commissioner Scott Gottlieb, M.D., on proposed new steps to protect youth by preventing access to flavored tobacco products and banning menthol in cigarettes. [press release]. Nov 15th 2018.

4. Gentzke AS CM, Cullen KA, Bridget K. Ambrose BK, Gordon Willis G, Jamal A, King BA, Vital Signs: Tobacco Product Use Among Middle and High School Students United States, 2011-2018. MMWR Morb Mortal Wkly Rep. 2019;68:157-64.

5. Statement from FDA Commissioner Scott Gottlieb, M.D., on new data demonstrating rising youth use of tobacco products and the agency's ongoing actions to confront the epidemic of youth e-cigarette use. [press release]. Feb 11th 2019.

6. McNeill A, Calder R, Bauld L, Robson D. Evidence review of e-cigarettes and heated tobacco products 2018: A report commissioned by Public Health England. London: Public Health England; 2018.

7. Eastwood B, Arnott D, Britton J, Cheeseman H, Jarvis MJ, McNeill A. Electronic cigarette use in young people in Great Britain 2013-2014. Public Health. 2015;129:11506. 
8. Eastwood B, Dockrell MJ, Arnott D, Cheeseman H, McNeill A. Electronic

cigarette use in young people in GreatBritain 2015-2016. Public Health. 2017;149:45-8.

9. Office on Smoking and Health. 2018 National Youth T obacco Survey:

Methodology Report. Atlanta, GA: U.S. Department of Health and Human Services,

Centers for Disease Control and Prevention, National Center for Chronic Disease

Prevention and Health Promotion, Office on Smoking and Health; 2018.

10. Levy DT, Warner KE, Cummings KM, Hammond D, Kuo C, Fong GT, et al.

Examining the relationship of vaping to smoking initiation among US youth and young adults: a reality check. Tobacco Control. 2018:tobaccocontrol-2018-054446.

11. Warner KE, Mendez D. E-cigarettes: Comparing the Possible Risks of Increasing Smoking Initiation with the Potential Benefits of Increasing Smoking Cessation. Nicotine Tob Res. 2019;21(1):41-7.

Supplementary Tables

\begin{tabular}{|c|c|c|c|c|c|c|c|c|c|c|c|}
\hline & \multicolumn{10}{|c|}{ Lifetime tobacco use history } & \multirow[b]{2}{*}{ Total } \\
\hline & \begin{tabular}{|l|} 
Never \\
used \\
any \\
tobacco \\
product
\end{tabular} & $\begin{array}{l}\text { Used } \\
\text { tobacco, but } \\
\text { not } \\
\text { combustible }\end{array}$ & \begin{tabular}{|l|} 
Tried \\
combustible, \\
but not \\
cigarette
\end{tabular} & \begin{tabular}{|l|}
1 or more \\
puffs, but \\
never whole \\
cigarette
\end{tabular} & 1 cigarette & $\begin{array}{l}2 \text { to } 5 \\
\text { cigarettes }\end{array}$ & $\begin{array}{l}6 \text { to } 15 \\
\text { cigarettes }\end{array}$ & \begin{tabular}{|l|}
16 to 25 \\
cigarettes
\end{tabular} & \begin{tabular}{|l|}
26 to 99 \\
cigarettes
\end{tabular} & \begin{tabular}{|l|}
$100+$ \\
cigarettes
\end{tabular} & \\
\hline $\begin{array}{l}\text { Used 1-19 } \\
\text { days\% }\end{array}$ & \begin{tabular}{|l|}
2.3 \\
$(1.5-3.5)$ \\
\end{tabular} & \begin{tabular}{|l|}
7.5 \\
$(3.3-16.1)$
\end{tabular} & \begin{tabular}{|l|}
13.3 \\
$(10.3-16.9)$ \\
\end{tabular} & \begin{tabular}{|l|}
16.6 \\
$(13.2-20.6)$
\end{tabular} & \begin{tabular}{|l|}
21.0 \\
$(14.6-29.1)$
\end{tabular} & $\begin{array}{l}25.6 \\
(20.3-31.8)\end{array}$ & \begin{tabular}{l|}
36.1 \\
$(30.0-42.7)$
\end{tabular} & \begin{tabular}{|l|}
35.8 \\
$(27.7-44.8)$
\end{tabular} & \begin{tabular}{|l|}
36.4 \\
$(27.6-46.2)$
\end{tabular} & \begin{tabular}{|l|}
39.8 \\
$(34.4-45.3)$
\end{tabular} & $\begin{array}{l}11.3 \\
(9.5-13.5) \\
\end{array}$ \\
\hline $\mathrm{n}$ & 144 & 13 & 195 & 185 & 57 & 161 & 110 & 69 & 97 & 234 & 1265 \\
\hline $\begin{array}{l}\text { Used 20+ days } \\
\%\end{array}$ & \begin{tabular}{|l|}
0.1 \\
$(0.0-0.2)$
\end{tabular} & $\begin{array}{l}0.5 \\
(0.1-3.5)\end{array}$ & \begin{tabular}{|l|l|}
0.9 \\
$(0.4-2.0)$ \\
\end{tabular} & \begin{tabular}{|l|}
1.0 \\
$(0.6-1.9)$
\end{tabular} & \begin{tabular}{|l|}
1.8 \\
$(0.6-5.1)$ \\
\end{tabular} & $\begin{array}{l}4.4 \\
(2.4-8.0)\end{array}$ & $\begin{array}{l}9.2 \\
(4.9-16.4)\end{array}$ & \begin{tabular}{|l|}
7.4 \\
$(4.4-12.2)$
\end{tabular} & \begin{tabular}{|l|}
10.5 \\
$(6.5-16.8)$ \\
\end{tabular} & \begin{tabular}{|l|}
16.5 \\
$(11.4-23.4)$
\end{tabular} & $\begin{array}{l}.1 \\
(1.5-2.8)\end{array}$ \\
\hline$n$ & 3 & 1 & 16 & 13 & 4 & 20 & 22 & 17 & 28 & 95 & 219 \\
\hline $\begin{array}{l}\text { Any past } \\
30 \text { days use }\end{array}$ & \begin{tabular}{|l|}
2.3 \\
$(1.5-3.6)$
\end{tabular} & $\begin{array}{l}8.0 \\
(3.7-16.7)\end{array}$ & \begin{tabular}{|l|}
14.2 \\
$(11.0-18.1)$
\end{tabular} & \begin{tabular}{|l|}
17.6 \\
$(14.1-21.8)$
\end{tabular} & \begin{tabular}{|l|}
22.7 \\
$(16.0-31.2)$
\end{tabular} & $\begin{array}{l}30.1 \\
(23.4-37.8)\end{array}$ & \begin{tabular}{|l|}
45.3 \\
$(37.8-53.0)$
\end{tabular} & \begin{tabular}{|l|}
43.2 \\
$(33.9-53.0)$
\end{tabular} & \begin{tabular}{|l|}
46.9 \\
$(37.0-57.1)$
\end{tabular} & \begin{tabular}{|l|}
56.3 \\
$(46.9-65.2)$
\end{tabular} & $\begin{array}{l}13.4 \\
(11.1-16.1)\end{array}$ \\
\hline & 147 & 14 & 211 & 198 & 61 & 181 & 132 & 86 & 125 & 329 & 1484 \\
\hline Base & 5974 & 169 & 1493 & 1202 & 266 & 627 & 339 & 208 & 283 & 591 & 11152 \\
\hline $\mathrm{OR}$ & 1.00 & \begin{tabular}{|l|}
3.6 \\
$(1.5-8.6)$
\end{tabular} & \begin{tabular}{|l|}
6.9 \\
$(4.5-10.5)$
\end{tabular} & \begin{tabular}{|l|}
8.9 \\
$(6.0-13.1)$
\end{tabular} & \begin{tabular}{|l|}
12.2 \\
$(7.6-19.6)$
\end{tabular} & $\begin{array}{l}17.9 \\
(11.5-27.8)\end{array}$ & $\begin{array}{l}34.4 \\
(22.5-52.5)\end{array}$ & \begin{tabular}{|l|}
31.6 \\
$(19.7-50.8)$
\end{tabular} & \begin{tabular}{|l|}
36.8 \\
$(22.8-59.3)$
\end{tabular} & \begin{tabular}{|l|}
53.6 \\
$(34.5-83.3)$
\end{tabular} & \\
\hline $\begin{array}{l}\text { Smoked cigs } \\
\text { p } 30 \text { days \% }\end{array}$ & - & r & $\begin{array}{l}0.2 \\
(0.1-0.4) \\
\end{array}$ & $\begin{array}{l}3.5 \\
(2.1-5.8) \\
\end{array}$ & \begin{tabular}{|l|}
7.8 \\
$(5.3-11.5)$
\end{tabular} & $\begin{array}{l}17.7 \\
(14.2-21.9)\end{array}$ & $\begin{array}{l}36.8 \\
(30.6-43.5)\end{array}$ & \begin{tabular}{|l|}
53.6 \\
$(45.4-61.7)$
\end{tabular} & \begin{tabular}{|l|}
67.6 \\
$(60.5-74.1)$
\end{tabular} & \begin{tabular}{|l|}
84.9 \\
$(80.9-88.1)$
\end{tabular} & $\begin{array}{l}9.3 \\
(8.2-10.5)\end{array}$ \\
\hline
\end{tabular}

Past-30-days use of e-cigarettes by lifetime tobacco use history among high school students

NYTS 2014 


\begin{tabular}{|c|c|c|c|c|c|c|c|c|c|c|c|}
\hline & \multicolumn{10}{|c|}{ Lifetime tobacco use history } & \multirow[b]{2}{*}{ Total } \\
\hline & $\begin{array}{l}\text { Never } \\
\text { used } \\
\text { any } \\
\text { tobacco } \\
\text { product }\end{array}$ & $\begin{array}{l}\text { Used } \\
\text { tobacco, but } \\
\text { not } \\
\text { combustible }\end{array}$ & $\begin{array}{l}\text { Tried } \\
\text { combustible, } \\
\text { but not } \\
\text { cigarette }\end{array}$ & $\begin{array}{l}1 \text { or more } \\
\text { puffs, but } \\
\text { never whole } \\
\text { cigarette }\end{array}$ & 1 cigarette & $\begin{array}{l}2 \text { to } 5 \\
\text { cigarettes }\end{array}$ & $\begin{array}{l}6 \text { to } 15 \\
\text { cigarettes }\end{array}$ & $\begin{array}{l}16 \text { to } 25 \\
\text { cigarettes }\end{array}$ & \begin{tabular}{|l|}
26 to 99 \\
cigarettes
\end{tabular} & \begin{tabular}{|l|}
$100+$ \\
cigarettes
\end{tabular} & \\
\hline $\begin{array}{l}\text { Used 1-19 } \\
\text { days\% }\end{array}$ & \begin{tabular}{|l|}
2.9 \\
$(2.2-3.8)$
\end{tabular} & \begin{tabular}{|l|}
15.6 \\
$(8.9-25.9)$
\end{tabular} & $\begin{array}{l}20.4 \\
(17.4-23.6)\end{array}$ & $\begin{array}{l}21.6 \\
(17.9-25.9)\end{array}$ & \begin{tabular}{|l|}
21.0 \\
$(14.7-29.2)$
\end{tabular} & $\begin{array}{l}35.2 \\
(28.3-42.7)\end{array}$ & $\begin{array}{l}32.5 \\
(25 . .1-40.9)\end{array}$ & $\begin{array}{l}37.8 \\
(27.5-49.4)\end{array}$ & \begin{tabular}{|l|}
27.2 \\
$(20.9-34.5)$ \\
\end{tabular} & \begin{tabular}{|l|}
41.8 \\
$(36.0-47.8)$
\end{tabular} & \begin{tabular}{|l|}
13.5 \\
$(11.9-15.2)$
\end{tabular} \\
\hline$n$ & 143 & 21 & 263 & 184 & 45 & 163 & 94 & 61 & 74 & 181 & 1229 \\
\hline $\begin{array}{l}\text { Used 20+ days } \\
\%\end{array}$ & $\begin{array}{l}0.2 \\
(0.1-0.4)\end{array}$ & \begin{tabular}{|l|}
0.9 \\
$(0.2-3.7)$ \\
\end{tabular} & $\begin{array}{l}1.7 \\
(1.1-2.6)\end{array}$ & $\begin{array}{l}1.5 \\
(1.0-2.4) \\
\end{array}$ & \begin{tabular}{|l|}
2.3 \\
$(0.7-7.1)$
\end{tabular} & $\begin{array}{l}4.2 \\
(2.6-6.9)\end{array}$ & $\begin{array}{l}6.9 \\
(3.7-12.4)\end{array}$ & $\begin{array}{l}9.2 \\
(4.6-17.6)\end{array}$ & \begin{tabular}{|l|}
14.2 \\
$(9.0-21.6)$ \\
\end{tabular} & \begin{tabular}{|l|}
20.4 \\
$(14.2-28.5)$
\end{tabular} & \begin{tabular}{|l|}
2.5 \\
$(1.9-3.2)$ \\
\end{tabular} \\
\hline$n$ & 8 & 2 & 18 & 19 & 5 & 20 & 18 & 11 & 27 & 90 & 218 \\
\hline $\begin{array}{l}\text { Any past } \\
30 \text { days use }\end{array}$ & \begin{tabular}{|l}
3.1 \\
$(2.3-4.0)$
\end{tabular} & \begin{tabular}{|l|l|}
16.5 \\
$(9.5-27.0)$ \\
\end{tabular} & $\begin{array}{l}22.0 \\
(18.8-25.6)\end{array}$ & $\begin{array}{l}23.1 \\
(19.2-27.5)\end{array}$ & \begin{tabular}{|l|}
23.3 \\
$(16.8-31.5)$
\end{tabular} & $\begin{array}{l}39.4 \\
(32.3-46.9)\end{array}$ & $\begin{array}{l}39.4 \\
(31.1-48.4)\end{array}$ & $\begin{array}{l}47.0 \\
(36.3-57.9)\end{array}$ & \begin{tabular}{|l|}
41.3 \\
$(33.9-49.2)$ \\
\end{tabular} & \begin{tabular}{|l|}
62.2 \\
$(53.3-70.4)$ \\
\end{tabular} & \begin{tabular}{|l|}
15.9 \\
$(14.0-18.1)$ \\
\end{tabular} \\
\hline Base & 5059 & 148 & 1277 & 933 & 203 & 505 & 280 & 161 & 233 & 429 & 9228 \\
\hline $\mathrm{OR}$ & 1.00 & \begin{tabular}{|l|}
6.2 \\
$(3.0-12.9)$ \\
\end{tabular} & $\begin{array}{l}8.9 \\
(6.7-11.9)\end{array}$ & $\begin{array}{l}9.5 \\
(7.1-12.7)\end{array}$ & \begin{tabular}{|l|}
9.6 \\
$(6.8-13.7)$ \\
\end{tabular} & $\begin{array}{l}20.6 \\
(14.9-28.5)\end{array}$ & $\begin{array}{l}20.6 \\
(13.6-31.0)\end{array}$ & $\begin{array}{l}28.1 \\
(17.7-44.5)\end{array}$ & \begin{tabular}{|l|}
22.3 \\
$(15.3-32.5)$ \\
\end{tabular} & \begin{tabular}{|l|}
52.1 \\
$(36.3-74.9)$ \\
\end{tabular} & \\
\hline $\begin{array}{l}\text { Smoked cigs } \\
\text { p } 30 \text { days } \%\end{array}$ & - & 1- & - & $\begin{array}{l}3.9 \\
(2.5-5.9)\end{array}$ & \begin{tabular}{|l|}
8.5 \\
$(4.9-14.3)$
\end{tabular} & $\begin{array}{l}18.9 \\
(15.2-23.3)\end{array}$ & $\begin{array}{l}36.6 \\
(30.0-43.7)\end{array}$ & $\begin{array}{l}52.9 \\
(43.3-62.4)\end{array}$ & \begin{tabular}{|l|}
62.7 \\
$(53.1-71.5)$ \\
\end{tabular} & \begin{tabular}{|l|}
88.7 \\
$(84.1-92.0)$
\end{tabular} & \begin{tabular}{|l|}
9.3 \\
$(7.8-10.9)$ \\
\end{tabular} \\
\hline
\end{tabular}

Current (past 30 days) use of e-cigarettes by lifetime tobacco use history among high school students NYTS 2015

\begin{tabular}{|c|c|c|c|c|c|c|c|c|c|c|c|}
\hline & \multicolumn{10}{|c|}{ Lifetime tobacco use history } & \multirow[b]{2}{*}{ Total } \\
\hline & $\begin{array}{l}\text { Never } \\
\text { used any } \\
\text { tobacco } \\
\text { product } \\
\end{array}$ & \begin{tabular}{|l|} 
Used \\
tobacco, \\
but not \\
combustible \\
\end{tabular} & \begin{tabular}{|l|} 
Tried \\
combustible, \\
but not \\
cigarette \\
\end{tabular} & \begin{tabular}{|l|}
1 or more \\
puffs, but \\
never whole \\
cigarette \\
\end{tabular} & 1 cigarette & \begin{tabular}{|l|}
2 to 5 \\
cigarettes
\end{tabular} & \begin{tabular}{|l|}
6 to 15 \\
cigarettes
\end{tabular} & $\begin{array}{l}16 \text { to } 25 \\
\text { cigarettes }\end{array}$ & $\begin{array}{l}26 \text { to } 99 \\
\text { cigarettes }\end{array}$ & $\begin{array}{l}100+ \\
\text { cigarettes }\end{array}$ & \\
\hline $\begin{array}{l}\text { Used 1-19 } \\
\text { days\% }\end{array}$ & \begin{tabular}{|l|}
2.5 \\
$(1.9-3.3)$
\end{tabular} & \begin{tabular}{|l|}
8.8 \\
$(4.6-16.3)$
\end{tabular} & \begin{tabular}{|l|}
12.9 \\
$(10.3-16.1)$
\end{tabular} & \begin{tabular}{|l|}
12.2 \\
$(9.7-15.1)$
\end{tabular} & \begin{tabular}{|l|}
16.3 \\
$(10.9-23.6)$
\end{tabular} & \begin{tabular}{|l|}
26.6 \\
$(21.4-32.6)$ \\
\end{tabular} & \begin{tabular}{|l|}
24.6 \\
$(18.1-32.6)$ \\
\end{tabular} & $\begin{array}{l}33.5 \\
(22.1-47.2)\end{array}$ & $\begin{array}{l}33.2 \\
(26.2-41.1)\end{array}$ & \begin{tabular}{|l|}
35.3 \\
$(28.0-43.4)$ \\
\end{tabular} & $\begin{array}{l}9.3 \\
(8.1-10.6)\end{array}$ \\
\hline$n$ & 152 & 13 & 156 & 124 & 36 & 110 & 52 & 47 & 81 & 130 & 901 \\
\hline $\begin{array}{l}\text { Used 20+ days } \\
\%\end{array}$ & \begin{tabular}{|l|}
0.1 \\
$(0.1-0.3)$
\end{tabular} & \begin{tabular}{|l|}
0.6 \\
$(0.1-2.6)$
\end{tabular} & \begin{tabular}{|l|}
1.6 \\
$(1.0-2.5)$
\end{tabular} & \begin{tabular}{|l|}
1.5 \\
$(0.7-3.1)$
\end{tabular} & \begin{tabular}{|l|}
3.5 \\
$(1.3-8.9)$
\end{tabular} & \begin{tabular}{|l|}
4.5 \\
$(2.3-8.8)$
\end{tabular} & $\begin{array}{l}5.7 \\
(2.8-11.1)\end{array}$ & $\begin{array}{l}10.9 \\
(6.5-17.7)\end{array}$ & $\begin{array}{l}10.3 \\
(6.0-17.0)\end{array}$ & \begin{tabular}{|l|}
16.6 \\
$(12.1-22.5)$
\end{tabular} & $\begin{array}{l}2.0 \\
(1.6-2.4)\end{array}$ \\
\hline $\mathrm{n}$ & 8 & 2 & 22 & 12 & 5 & 15 & 14 & 17 & 22 & 76 & 193 \\
\hline $\begin{array}{l}\text { Any past } \\
30 \text { days use }\end{array}$ & $\begin{array}{l}2.6 \\
(2.0-3.4)\end{array}$ & \begin{tabular}{|l|}
9.4 \\
$(5.1-16.7)$
\end{tabular} & \begin{tabular}{|l|}
14.6 \\
$(11.7-18.0)$
\end{tabular} & \begin{tabular}{|l|}
13.7 \\
$(10.9-16.9)$
\end{tabular} & \begin{tabular}{|l|}
19.8 \\
$(14.5-26.4)$
\end{tabular} & \begin{tabular}{|l|}
31.1 \\
$(24.9-38.1)$
\end{tabular} & \begin{tabular}{|l|}
30.6 \\
$(23.4-38.8)$
\end{tabular} & $\begin{array}{l}44.4 \\
(30.9-58.7)\end{array}$ & $\begin{array}{l}43.5 \\
(35.0-52.4)\end{array}$ & $\begin{array}{l}51.9 \\
(43.8-60.0)\end{array}$ & $\begin{array}{l}11.3 \\
(9.8-12.9)\end{array}$ \\
\hline & 159 & 15 & 179 & 136 & 41 & 125 & 66 & 64 & 103 & 206 & 1094 \\
\hline Base & 6370 & 133 & 1387 & 1030 & 199 & 468 & 253 & 161 & 225 & 393 & 10619 \\
\hline OR & 1.00 & \begin{tabular}{|l|}
3.9 \\
$(2.1-7.2)$ \\
\end{tabular} & \begin{tabular}{|l|}
6.4 \\
$(4.8-8.5)$
\end{tabular} & \begin{tabular}{|l|}
5.9 \\
$(4.4-8.0)$
\end{tabular} & \begin{tabular}{|l|}
9.2 \\
$(6.6-13.0)$
\end{tabular} & \begin{tabular}{|l|}
16.9 \\
$(11.7-24.5)$
\end{tabular} & \begin{tabular}{|l|}
16.5 \\
$(10.5-25.9)$
\end{tabular} & $\begin{array}{l}29.8 \\
(15.8-56.2)\end{array}$ & $\begin{array}{l}28.8 \\
(19.0-43.5)\end{array}$ & \begin{tabular}{|l|}
40.4 \\
$(26.0-63.0)$ \\
\end{tabular} & \\
\hline $\begin{array}{l}\text { Smoked cigs } \\
\text { p } 30 \text { days } \%\end{array}$ & - & & \begin{tabular}{|l|}
0.2 \\
$(0.1-0.6)$
\end{tabular} & \begin{tabular}{|l|}
2.6 \\
$(1.7-3.8)$
\end{tabular} & \begin{tabular}{|l}
9.5 \\
$(5.2-16.8)$
\end{tabular} & \begin{tabular}{|l|l}
16.5 \\
$(11.9-22.4)$
\end{tabular} & \begin{tabular}{|l}
36.4 \\
$(29.4-44.1)$
\end{tabular} & $\begin{array}{l}45.7 \\
(36.3-55.4)\end{array}$ & $\begin{array}{l}57.5 \\
(50.7-64.1)\end{array}$ & $\begin{array}{l}89.3 \\
(84.8-92.6)\end{array}$ & $\begin{array}{l}8.0 \\
(6.7-9.5)\end{array}$ \\
\hline
\end{tabular}

Current (past 30 days) use of e-cigarettes by lifetime tobacco use history among high school students NYTS 2016 